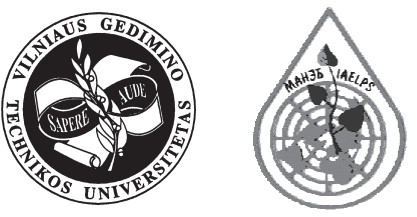

\title{
IMPACT OF ROAD MAINTENANCE SALTS ON WATER ECOSYSTEMS ACCORDING TO DIATOM FLORA INVESTIGATION
}

\author{
Vytautas Oškinis $^{1}$, Tomas Kasperovičius ${ }^{2}$ \\ Dept of Environmental Protection, Vilnius Gediminas Technical University, \\ Sauletekio 11, LT-10223 Vilnius-40, Lithuania \\ E-mail: 1aak@ap.vtu.lt; ${ }^{2}$ tomaskasp@gmail.com \\ Received 25 Dec 2004; accepted 25 Feb 2005
}

\begin{abstract}
Road maintenance chlorides have a negative environmental impact. Chemical solutions of melting snow inevitably get into the soil and change its chemical composition. They also get into ponds. Five water basins in Vilnius city, at 5-80 m from roads, were chosen for investigation. The highest chloride concentrations were established by roads where winter road maintenance is performance at the highest level. The hydrophysical and chemical parameters of the investigated lakes depend on anthropogenic processes. Diatoms were used as indicators for reconstruction of the paleoecological history of the lakes. They respond sensitively to changes in lake water salinity. The total number of 35 indifferentic-halophilic species from all the 78 diatom taxa were identified in the lake bottom sediments. Fluctuations of their abundance could be caused by the impact of salts in different periods stimulating the productivity of indifferentichalophilic species.
\end{abstract}

Keywords: road maintenance salts, water basins, diatoms, sediments.

\section{Introduction}

The roads of the Republic of Lithuania are maintained in winter conditions almost 5 months per year [1]. It is caused by geographical position and climate. During winter road maintenance to avoid road slippery fractional materials (mostly sand), chemical substances (mostly salts) and their blends are used. Salts react with ice and solutions which do not freeze are the result of this chemical process. Chlorides used for road maintenance have a negative environmental impact. Chemical solutions of melting snow inevitably get into the soil and change its chemical composition. They also get into water ponds.

Degradation of water quality as a result of human activities is a major contemporary concern. Now freshwater ecosystems become increasingly threatened by salinity because of rising saline groundwater and modification of water regime reducing the frequency of highflow (flushing) events, resulting in an accumulation of salts. Salinization can lead to changes in a physical environment that will affect water ecosystem processes. There is limited information on how increasing salinity will affect various life stages of water biota [2].

In lakes salinity gradients may strongly influence the abundance and taxonomic composition of aquatic communities. Data on plankton community fluctuations are often used to estimate salinity impact on lake ecosystems. Diatoms are potentially good indicators for reconstruction of the paleoecological history of any lake. Diatom taxa have tolerance of a wide range of environmental parameters, such as light, moisture, current velocity, $\mathrm{pH}$, salinity, oxygen and inorganic and organic nutrients [3]. Studies on diatoms from water ecosystem sediments are commonly used in assessing present and past ecological conditions of a variety of types of water basins.

In Lithuania palaeosalinity reconstruction of the Baltic Sea and the Curonian Lagoon using diatoms were performed by M. Kabailienè [4-6], G. Vaikutienè [7, 8] and A. Bitinas et al [9].

The aim of this investigation is to study chloride concentrations in roadside snow and a distance from roads where the highest chloride amounts accumulate as well as to investigate salinity impact on the physical and biotic components of aquatic ecosystems. 


\section{Materials and methods}

Five water basins in Vilnius city, situated at 5-80 m from roads, were chosen for investigation (Fig 1). Close to lakes samples of roadside snow were taken on 12 February 2004 at a temperature of $13-16{ }^{\circ} \mathrm{C}$, the wind speed of 6-8 m/s, atmospheric pressure of $1001,1 \mathrm{~Pa}$. In accordance with meteorological data, a permanent snow level was formed on 3 February 2004. Day samples were taken from a medium snow layer of approximately $19 \mathrm{~cm}$.

For snow sampling a transverse cross-section was composed: point 1 - on the edge of a road; point 2 - at $1 \mathrm{~m}$ distance from a road; point 3 - at $2 \mathrm{~m}$ distance; point 4 - at $3 \mathrm{~m}$ distance; point 5 - at $4 \mathrm{~m}$ distance. In this way the distribution of chloride concentrations was measured perpendicular to a road. At each measurement point at $10 \mathrm{~m}$ distance from one another five longitudinal cross-sections parallel to roads were made. Chloride concentrations in dissolved snow water were established by the titrimetric method.

Hydrophysical and chemical parameter measurements were made in April-August 2004 in Gineitiškès, Jeruzalè, Ežerèliai and Verkiai water basins. Water temperature, conductivity, $\mathrm{pH}$, and Eh were measured there with a MultiLine P4/SET using selective electrodes SenTix ORO and TetraCon 325. The Winkler method was used to assess dissolved oxygen concentrations in water [10]. Transparency was estimated with a Secchi disk.

Two short sediment cores $(40 \mathrm{~cm})$ for diatom analyses were taken by modified Kajak $(3 \mathrm{~cm}$ in diameter)

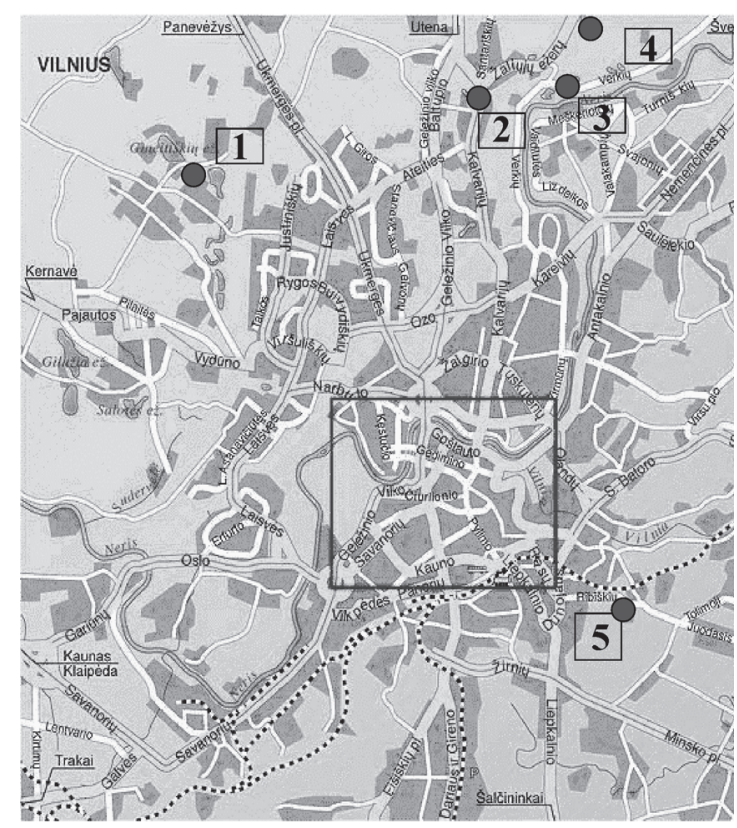

Fig 1. Scheme of sampling sites:

1 - the Gineitiškès lake (Gineitiškès street), 2 - the Jeruzale lake (Kalvarijos street), 3 - the Verkiai pond (Žalieji ežerai street), 4 - the Ežerèliai pond (Žalieji ežerai street); 5 - the Slènis pond (Ribiškès street). gravity core from the deepest part of the Gineitiškes lake and the Verkiai pond. Diatom communities at $1 \mathrm{~cm}$ intervals of the core were analysed.

Preparations of diatom slides for microscopy were made after Kelly et al, algae were identified using taxonomic literature by K. Krammer and H. Lange-Bertalot [11-14]. Quantitative data were obtained by counting the minimum of 250 diatoms valve per slide. Species abundance and distribution were calculated as a percentage of the total number of diatom valves. Diatom ecological interpretations were based upon the work of H. Van Dam et al [3].

\section{Results and discussion}

\subsection{Chloride concentration in dissolved snow water}

The highest chloride concentrations of roadside snow were found at a distance of $0-1 \mathrm{~m}$ from a road. It reaches $3120 \mathrm{mg} / \mathrm{l}$ (close to the Verkiai pond), $\mathrm{pH}$ of dissolved snow water is between 7,2-7,4. Moving farther from a road chloride concentration noticeably decreases. At $4 \mathrm{~m}$ distance it accounts for 5-10\% of the highest chloride concentration (Table 1). Maximal chloride concentrations were founding by roads where winter road maintenance is performed at the highest level. By Ribiškès street, where winter road maintenance is performed at a medium level, chloride concentrations in dissolved snow water are much lower $(\max -1440 \mathrm{mg} /$ $1, \min -75 \mathrm{mg} / \mathrm{l})$.

Table 1. Chloride concentration distribution

\begin{tabular}{|l|c|c|c|c|c|}
\hline \multirow{2}{*}{ Street } & \multicolumn{5}{|c|}{$\begin{array}{c}\text { Chloride concentration distribution (mg/l) } \\
\text { in accordance with distance }\end{array}$} \\
\cline { 2 - 6 } & $0 \mathrm{~m}$ & $1 \mathrm{~m}$ & $2 \mathrm{~m}$ & $3 \mathrm{~m}$ & $4 \mathrm{~m}$ \\
\hline $\begin{array}{l}\text { Kalvarijos str } \\
\text { (the Jeruzale lake) }\end{array}$ & 2800 & 2900 & 1920 & 890 & 280 \\
\hline $\begin{array}{l}\text { Žalieji ežerai str } \\
\text { (the Verkiai pond) }\end{array}$ & 3120 & 2950 & 2100 & 1045 & 260 \\
\hline $\begin{array}{l}\text { Žalieji ežerai str } \\
\text { (the Ežerèliai } \\
\text { pond) }\end{array}$ & 2510 & 2100 & 1840 & 780 & 125 \\
\hline $\begin{array}{l}\text { Ribiškés str } \\
\text { (the Slènis pond) }\end{array}$ & 1440 & 910 & 685 & 320 & 75 \\
\hline $\begin{array}{l}\text { Gineitiškės str (the } \\
\text { Gineitiškès lake) }\end{array}$ & 2700 & 2850 & 1800 & 650 & 220 \\
\hline
\end{tabular}

In all the cases the layer of land determines that part of dissolved snow water on roadsides gets into the water basins.

\subsection{Hydrophysical and chemical parameters}

At the beginning of the study period samples were taken from ice-free areas on 3 April 2004. Water temperature varied between 3,2 and $6,2{ }^{\circ} \mathrm{C}$. During the spring and at the beginning of the summer the temperature was relatively low reaching $15,2{ }^{\circ} \mathrm{C}$ in June. The hydrophysical and chemical parameters of the investigated lakes water are given in Table 2. 
Table 2. Hydrophysical and chemical parameter measurements in 2004

\begin{tabular}{|c|c|c|c|c|c|c|}
\hline $\begin{array}{l}\text { Lakes/ } \\
\text { ponds }\end{array}$ & Date & $\begin{array}{c}\text { Water } \\
\text { tempe- } \\
\text { rature, } \\
{ }^{\circ} \mathrm{C}\end{array}$ & $\mathrm{pH}$ & $\begin{array}{l}\text { Eh, } \\
\mathrm{mV}\end{array}$ & $\begin{array}{l}\text { Con- } \\
\text { ducti- } \\
\text { vity, } \\
\mu \mathrm{S} / \mathrm{cm}\end{array}$ & $\begin{array}{c}\mathrm{O}_{2}, \\
\mathrm{mg} / \mathrm{l}\end{array}$ \\
\hline \multirow{4}{*}{$\begin{array}{l}\text { The } \\
\text { Verkiai } \\
\text { pond }\end{array}$} & 0403 & 6,2 & 8,20 & -55 & 427 & 15,04 \\
\hline & 0512 & 8,3 & 7,86 & -50 & 411 & 14,00 \\
\hline & 0528 & 14,0 & 7,80 & -51 & 410 & 12,30 \\
\hline & 0610 & 15,2 & 8,20 & -69 & 399 & 11,20 \\
\hline \multirow{4}{*}{$\begin{array}{l}\text { The } \\
\text { Jeru- } \\
\text { zale } \\
\text { lake }\end{array}$} & 0403 & 5,3 & 7,87 & -43 & 450 & 16,00 \\
\hline & 0512 & 8,6 & 7,90 & -45 & 385 & 13,30 \\
\hline & 0528 & 13,1 & 7,91 & -47 & 380 & 12,80 \\
\hline & 0610 & 16,7 & 7,97 & -55 & 370 & 11,20 \\
\hline \multirow{4}{*}{$\begin{array}{l}\text { The } \\
\text { Ežeré- } \\
\text { liai } \\
\text { pond }\end{array}$} & 0403 & 3,2 & 7,60 & -39 & 461 & 13,02 \\
\hline & 0512 & 8,0 & 7,85 & -50 & 440 & 12,80 \\
\hline & 0528 & 13,6 & 7,90 & -52 & 422 & 12,80 \\
\hline & 0610 & 15,5 & 7,92 & -51 & 430 & 12,60 \\
\hline \multirow{4}{*}{$\begin{array}{l}\text { The } \\
\text { Ginei- } \\
\text { tiškès } \\
\text { lake }\end{array}$} & 0503 & 18,5 & 9,20 & - & 155 & 7,68 \\
\hline & 0606 & 17,9 & - & - & 151 & 8,88 \\
\hline & 0618 & 18,0 & 8,90 & -107 & 152 & 9,12 \\
\hline & 0809 & 18,9 & 9,49 & -130 & 155 & 6,88 \\
\hline
\end{tabular}

"-“" - no data

In the investigated lakes the values of $\mathrm{pH}>7$ were recorded. They ranged from 7,6 to 9,49 with increasing trend in summer. Redox potential values were negative and showed little variation between the two seasons in all the investigated lake. Conductivity values in the Gineitiškès lake were rather homogenous during the investigation period $-153 \mu \mathrm{S} / \mathrm{cm}$. In the other lakes conductivity was more than 3 times higher. The values decreased from spring to summer.

Concentrations of dissolved oxygen in the lakes and ponds ranged from 11,2 to $15,04 \mathrm{mg} / 1$ indicating saturation. The highest values were recorded just after icebreak. A decrease in oxygen concentration in late spring and summer can be attributed to increased temperature during the period.

Secchi depth fluctuated from 0,25 to $3,3 \mathrm{~m}$. These values show that light does not always reach the lake bottom.

\subsection{Diatoms in lake bottom sediments}

One-year investigation of zooplankton structure in three lakes did not show the influence of salts on their communities despite quite large amounts of chloride salts in the snow taken close to the lakes during the winter season in 2003-2004 (Table 1). Diatom communities are sensitive to a wide range of water quality degradation. They can indicate the overall toxicity (cumulative and synergistic) of contaminants. Long-term investigation of salt influence on the lake environment, according to diatom flora in the bottom sediments of the Gineitiškès lake and the Verkiai pond, was performed.

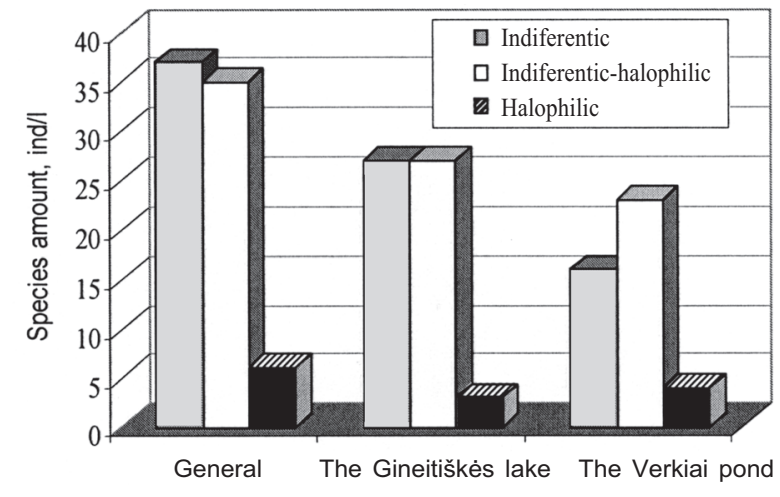

Fig 2. Species number of different diatom ecological groups

The total number of 78 diatom species was identified in the lake bottom sediments. 57 diatom taxa were found in the Gineitiškes lake, and 43 - in the Verkiai pond. The largest amount of species from benthic Navicula (10 species) and periphytic Cymbella (9), Achnanthes (8), Fragilaria (7) diatom genus was found.

Diatoms from different habitats and life form indicate the depth of water basin ecosystems during their different development periods. Plankton diatoms living in open water, periphytic attached to plants and benthic living in and on sediments are distinguished. In the investigated lake sediments the largest amount (57 species) is formed by periphytic, by benthic - 22 species and by planktonic - 11 species. In the Gineitiškès lake and the Verkiai pond periphytic and benthic dominate, accordingly, 29, 34 and 18, 12 diatom species.

Diatoms respond sensitively to changes in lake water salinity. In freshwaters, brackish and marine waters different species appear. In the investigated water basin sediments freshwater indifferentic diatoms (37 species) and indifferentic-halophilic (35 species) dominate (Fig 2).

Diatoms in the Verkiai pond sediments. The sediments of the $40 \mathrm{~cm}$ core consist of a dark-grey to olivegrey sandy mud and some shell fragments.

A selected diatom diagram showing taxa with an abundance of more than $5 \%$ in any sample-analysing diagram was constructed. The diatom taxa was combined into different life forms.

The patterns of changes do not relate to diatom diversity patterns. There was a clear succession in periphytic species during the whole investigation period. Freshwater periphytic diatoms Fragilaria brevistriata, $F$. construens, $F$. construens var. binodis, $F$. c. var. triundulata, F. c. var. venter, Achnanthes minutissima, Opephora martyi form a stable diatom community in the whole sediment core. These species contribute up to $90 \%$ of the total diatom flora. Dominance of periphytic species shows a low ecosystem water level. From the middle of the core and upwards the abundance of planktonic, typical of mesotrophic-euthrofic water species Cyclotella distinguenda and Stepahanodiscus minutulus increases. Almost in all the samples reophilic Rhoicosphenia curvata appear which indicate flowing conditions. 
According to adaptation to water salinity in the Verkiai pond sediments, freshwater indifferentic species (Fragilaria) dominated. There are large amounts of indifferentic-halophilic periphytic and benthic Achnanthes, Amphora, Navicula, Rhopalodia genus species. It is difficult to recognize salinization process impact on algae structure in shallow flowing ecosystems. However, fluctuations of halophilic diatom abundance along the whole Verkiai pond sediment core are seen. This could be caused by an increased access of salts in different periods, stimulating the productivity of indifferentic-halophilic species.

Diatoms in the Gineitiškès lake sediments. From the central part of the Gineitiškès lake a $26 \mathrm{~cm}$ sediment core was taken for diatom analyses.

The diatoms found in the core studied are mainly like those in the Verkiai pond periphytic Fragilaria species, indicating a macrophytic shallow water basin.

Twenty seven idifferentic-halophilic, tolerant to salinity species, were identified in the bottom sediments. They are abundant in all the sediment samples. However, from middle to lower deposits the largest amount of this ecological group diatom was found. Achnanthes and Stephanodiscus species prevail. Planktonic diatoms found in the sediments seem to be favoured by increased input of nutrients.

The Gineitiškès lake is a hypertrophic water basin. During the whole vegetation period cyanobacteria and green algae dominate in its water and form water blooms. During the investigation period in 2004 algae bloom was apparent, transparency reached only $0,25 \mathrm{~m}$.

A low diversity and abundance of indifferentic-halophilic diatoms and a high abundance and diversity of eutrophicated water diatoms seem to be the result of an influx of nutrients and pollutants in the Gineitiškès lake water and sediments.

\section{Conclusions}

1. The highest chloride concentrations are established by roads where winter road maintenance is performed at the highest level.

2. Hydrophysical and chemical parameters of the investigated water basins 5-80 m from roads depend on anthropogenic processes.

3. Diatom flora established in the Verkiai pond and the Gineitiškès lake sediments is typical of shallow macrophytic water basins. Freshwater indifferentic species from Fragilaria genus and indifferentic-halophilic Achnanthes, Amphora genus species prevail.

4. It may be concluded that diatom communities from the Verkiai pond sediments reflect salinity variations of environmental conditions through variations in indifferentic-halophilic species composition and abundance.

5. A low diversity and abundance of indifferentichalophilic diatoms and a high abundance and diversity of eutrophicated water diatoms seem to be the result of influx of nutrients and pollutants in the Gineitiškès lake water and sediments.

\section{Acknowledgements}

The authors express their gratefulness to the staff of Laboratory of Hydrobotany institute of Botany for help providing physical, chemical water analyses, and special thanks to Dr S. Mažeikaite for her comments on biological water investigation.

\section{References}

1. Oškinis, V.; Kinduryte, R.; Butkus, D. Evaluation of car noise on the highway Vilnius - Kaunas - Klaipeda. Journal of Environmental Engineering and Landscape Management, Vol XII, Suppl 1, Vilnius: Technika, 2004, p 1018 (in Lithuanian).

2. Laurinavičius, A., Čygas, D. Chemical substances for maintenance of motor roads and street paving in winter. Environmental Engineering (Aplinkos inžinerija), No 2(6), Vilnius: Technika, 1996, p 60-65 (in Lithuanian).

3. Van Dam, H.; Mertens, A.; Sinkeldam, J. A coded checklist and ecological indicator values of freshwater diatoms from the Netherlands. Netherlands Journal of Aquatic Ecology, Vol 28, No 1, Amsterdam: Springer Netherlands, 1994, p 117-133.

4. Kabailienè, M. The Baltic Ice Lake and Yoldia Sea stages on data from diatom analysis in the Central, South-Eastern Baltic. Quaternary International, Vol 27, Leiden: Elsewier, 1995, p 69-72.

5. Kabailienè, M. Water level changes in the SE Baltic during the Ancylus and Litorina stages based on diatom stratigraphy in Quaternaria. Quaternaria, Series A, Vol 7, Stockholm, 1999, p 39-44.

6. Kabailienè, M. Water level changes in SE Baltic based on diatom stratigraphy of Late glacial and Holocene deposits. Geology (Geologija), Vol 29, Vilnius: Academia, 2000, p 15-29 (in Lithuanian).

7. Vaikutienè, G. Evolution stage description of SE part of the Baltic Sea sustaining diatom analysis. The Geographic Yearbook (Geografijos metraštis), Vol 32. Vilnius: Institute of Geography, 1999, p 149-157 (in Lithuanian).

8. Vaikutiene, G. Diatom composition of the surface layer bottom sediments in the Curonian Lagoon (Lithuanian water area). In: $18^{\text {th }}$ International Diatom Symposium: $2-$ 7 September 2004, Poland. Miźdzyzdroje, 2004, p 228.

9. Bitinas, A.; Damušyte, A.; et al. Stratigraphic correliation of Late - Weichselian and Holocene deposits in the Lithuanian coastal region. Proceedings of Estonian Academy of Science. Ser. Geology, Vol 49, No 3, Tallinn: Akadeemia, 2000, p 200-217.

10. Merkelienè, R.; Čeponyte, V. Unity sewage and water body quality methods of investigation. Part I. Vilnius: Department of Environmental Protection, 1994. 221 p (in Lithuanian).

11. Krammer, K.; Lange-Bertalot, H. Süāwasserflora von Mitteleuropa. Bacillariophyceae, Vol 1. Naviculaceae. Stuttgart: Gustav Fisher Verlag, 1986. 876 p.

12. Krammer, K.; Lange-Bertalot, H. Süāwasserflora von Mitteleuropa. Bacillariophyceae, Vol 2. Bacillariaceae, 
Epithemiaceae, Suririllaceae. Stuttgart: Gustav Fisher Verlag, 1988. 596 p.

13. Krammer, K.; Lange-Bertalot, H. Süāwasserflora von Mitteleuropa. Bacillariophyceae. Vol 3. Centrales, Fragillariaceae, Eunotiaceae. Stuttgart: Gustav Fisher
Verlag, 1991. $576 \mathrm{p}$.

14. Krammer, K.; Lange-Bertalot, H. Süāwasserflora von Mitteleuropa. Bacillariophyceae, Vol 4. Achnanthaceae, Kritische Erganzungen zu Navinula (Lineolateae) und Gomphonema. Stuttgart: Gustav Fisher Verlag, 1991. 436 p.

\section{KELIŲ PRIEŽIŪRAI NAUDOJAMŲ DRUSKŲ ITAKA TITNAGINIŲ DUMBLIŲ IVAIROVEI}

\section{Oškinis, T. Kasperovičius}

S a n tra u a

Žiemą kelių priežiūrai naudojamos druskos teršia pakelių aplinką ir jos komponentus. Tirpstant sniegui susidarę druskų tirpalai patenka $\mathfrak{i}$ vandens telkinius. Tyrimai atlikti Vilniaus miesto ežeruose ir tvenkiniuose, 5-80 $\mathrm{m}$ atstumu nutolusiuose nuo intensyvaus autotransporto eismo gatvių.

Didžiausios chloridų koncentracijos (iki 3120 mg/l) nustatytos gatvėse, kurių priežiūra žiemą atliekama pagal I (aukščiausiąji) lygi. Hidrofizikiniai ir cheminiai parametrai priklauso nuo konkrečiame vandens telkinyje vykstančių antropogeninių procesų.

Verkių tvenkinio ir Gineitiškių ežero nuosėdu storymėje nustatyta sekliems makrofitiniams vandens telkiniams būdinga titnaginių dumblių flora. Vyrauja gèlavandenès - interferentinès (Fragilaria) ir indiferentinès - halofilinès (Achnanthes, Amphora) rūšys.

Skirtingais abiejų vandens telkinių formavimosi laikotarpiais nustatyta indiferentinių - halofilinių rūšiu pagausėjimas. Viena iš priežasčiu, galèjusių turèti įtakos druskingiems vandenims būdingų titnaginių dumblių išplitimui gali būti kelių priežiūrai naudojamos druskos (chloridai).

Raktažodžiai: kelių priežiūros druskos, vandens telkiniai, titnaginiai dumbliai.

\section{ВЛИЯНИЕ СОЛЕЙ, ПРИМЕНЯЕМЫХ ПРИ УХОДЕ ЗА ДОРОГАМИ В ЗИМНИХ УСЛОВИЯХ, НА ФЛОРУ ДИАТОМНЫХ ВОДОРОСЛЕЙ}

\section{В. Ошкинис, Т. Касперовичюс}

Р е 3 ю м е

Соли, применяемые при уходе за дорогами в зимних условиях, негативно влияют на придорожную среду и ее компоненты. Растворы солей, образующиеся при таянии снега, попадают в природные водоемы. Исследования проводились в озерах и прудах на территории г. Вильнюса. Эти водоемы находятся на расстоянии 5-80 м от дорог с интенсивным движением автотранспорта.

Максимальные концентрации хлоридов (до 3120 мг/л) зафиксированы на дорогах, уход за которыми в зимний сезон обеспечивается по высшей категории. Гидрофизические и химические параметры в конкретном водоеме зависят от характера антропогенной нагрузки.

В колонке отложений пруда Веркяй и озера Гинейтишкес установлена флора диатомных водорослей, характерная для мелководных макрофитных водоемов. Преобладают пресноводно-индифферентные (Fragilaria) и индифферентногалофильные (Achnanthes, Amphora) виды.

В обоих водоемах установлен происходивший в прошлом рост численности индифферентно-галофильных видов. Одной из возможных причин развития диатомных водорослей, характерных для солоноватых вод, является применение солей (хлоридов) при уходе за дорогами в зимних условиях.

Ключевые слова: соли, водоемы, диатомные водоросли.

Vytautas OŠKINIS. Dr, Assoc Prof, Dept of Environmental Protection, Vilnius Gediminas Technical University (VGTU), Sauletekio al. 11, LT-10223 Vilnius-40, Lithuania.

Doctor of Natural Sciences (biology; ecology), Institute of Ecology, 1993. First degree in Biology, Vilnius University (VU), 1982. Employment: Associate Professor, VGTU, 1993; Institute of Ecology, 1984-1992. Publications: author of about 50 scientific publications. Research interests: applied ecology, environmental pollution.

Tomas KASPEROVIČIUS. Master student, Vilnius Gediminas Technical University (VGTU), Saulètekio al. 11, LT-10223 Vilnius-40, Lithuania.

Bachelor of Science (environmental engineering), VGTU, 2003. Research interests: applied ecology. 